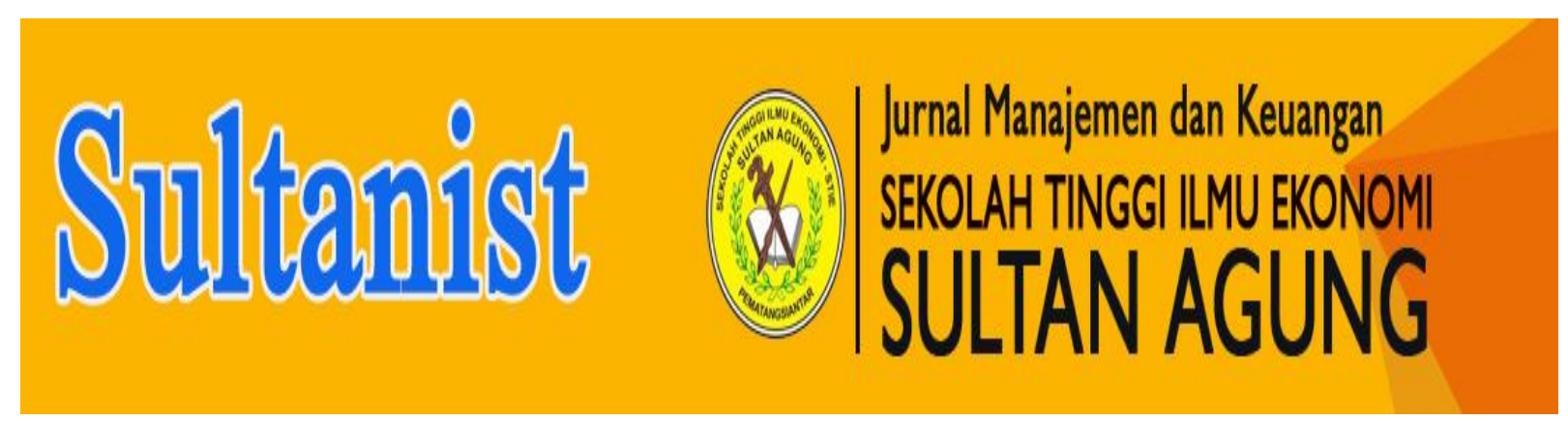

\title{
PENGARUH PROFITABILITAS TERHADAP NILAI PERUSAHAAN DENGAN LEVERAGE SEBAGAI VARIABEL MODERATING PADA PERUSAHAAN SUB SEKTOR FARMASI YANG TERDAFTAR DI BURSA EFEK INDONESIA
}

\author{
Oleh : \\ Maria Emas P. Siallagan \\ S1 Akuntansi \\ Yansen Siahaan, Jubi, Ady Inrawan
}

\begin{abstract}
Abstrak
Tujuan dari penelitian ini adalah untuk mengetahui gambaran profitabilitas, nilai perusahaan, dan leverage, untuk mengetahui pengaruh profitabilitas terhadap nilai perusahaan dan untuk mengetahui kemapuan leverage dalam memoderasi hubungan profitabilitas dengan nilai perusahaan pada Perusahaan Sub Sektor Farmasi yang Terdaftar di Bursa Efek Indonesia. Penelitiaan ini dilakukan dengan metode analisis deskriptif kualitatif dan analisis deskriptif kuantitatif. Pengumpulan data digunakan metode dokumentasi. Teknik analisis yang digunakan adalah regresi linier sederhana, regresi moderasi, koefisien korelasi, koefisien determinasi dan uji hipotesis. Analisis data dengan bantuan program SPSS versi 20.

Hasil penelitian ini dapat disimpulkan sebagai berikut: 1. Rata-rata ROE mengalami fluktuasi dan cenderung menurun, rata-rata DER mengalami fluktuasi dan cenderung meningkat, dan rata-rata PBV mengalami fluktuasi dan cenderung meningkat. 2. Hasil pengujian regresi linear sederhana diketahui bahwa profitabilitas berpengaruh negatif terhadap nilai perusahaan. 3 . Hasil pengujian regresi moderasi diketahui bahwa leverage memperlemah hubungan profitabilitas dengan nilai perusahaan. 4. Hasil uji hipotesis pertama dapat disimpulkan bahwa profitabilitas berpengaruh negatif tidak signifikan terhadap nilai perusahaan. 5. Hasil uji hipotesis kedua dapat disimpulkan bahwa leverage mampu memoderasi namun tidak signifikan hubungan antara profitabilitas dengan nilai perusahaan. Hasil penelitian menyarankan agar perusahaan meningkatkan penjualan untuk mengoptimalkan laba, menggunakan hutang untuk meningkatkan produktivitas perusahaan, mengendalikan manajemen yang ada pada perusahaan dengan baik dan membagikan dividen kepada pemegang saham.
\end{abstract}

Kata Kunci : Profitabilitas, Leverage, dan Nilai Perusahaan

\section{Abstract}

The purposes of this research are to know the description of profitability, firm value, and leverage, to determine the effect of profitability on the value and to determine leverage ability to moderated profitability reletionships with firm value at Farmasi Sub-Sector Company listed on the Indonesia Stock Exchange. The research was conducted with qualitative descriptive analysis method and quantitative descriptive analysis. The data are collected by using documentation method. The analysis technique used simple linear regression, moderation regression, correlation coefficient, determination coefficient and hypothesis test. Data are analysed with the help of SPSS version 20.

The results of this research be summarized as follows: 1. Average ROE fluctuated and tended to decline, the average DER fluctuated and tended to increase, and the average PBV fluctuated and tended to increase. 2. The results of simple linear regression test showed that profitability has negative effect on firm value. 3. The results of the moderation regression test showed that leverage weakens the profitability relationship with the value. 4. The results of testing the first hypothesis can be concluded that profitability has a negative effect not significant on firm value. 5 . The results of the second hypothesis test can be concluded that leverage is able to moderate the relationship between profitability and firm value. The research suggest that companies increase sales to optimize profits, use debt to increase company productivity, control the existing management of the company and distribute dividend to shareholders.

Keywords : Profitability, Leverage, and Firm Value

\section{PENDAHULUAN}

1.1 Latar Belakang Masalah

Suatu perusahaan yang baik harus mampu mengelolah potensi finansial maupun potensi non finansial di dalam meningkatkan nilai perusahaan untuk eksistensi perusahaan dalam jangka panjang. Memaksimalkan nilai perusahaan sangat penting bagi suatu perusahaan, karena dengan memaksimalkan nilai perusahaan berarti juga memaksimalkan kemakmuran pemegang saham yang merupkan salah satu tujuan perusahaan.

Nilai perusahaan dapat menjadi gambaran atas keadaan perusahaan yang dapat 
mempengaruhi persepsi investor terhadap perusahaan yang bersangkutan. bertambah. Perusahaan dipandang memiliki nilai perusahaan yang tinggi apabila kinerja perusahaannya baik.

Dalam hal finansial, berbagai aspek keuangan di dalam perusahaan berpengaruh signifikan terhadap nilai perusahaan, salah satunya rasio profitabilitas. Semakin tinggi kemampuan perusahaan menghasilkan laba maka semakin tinggi juga tingkat pengembalian saham pada investor, sehingga menjadikan nilai perusahaan menjadi lebih baik.

Selain profitabilitas nilai perusahaan juga dapat dipengaruhi oleh tingkat leverage atau hutang yang digunakan perusahaan untuk mendanai aktivitas perusahaan. Semakin sukses perusahaan, kemungkinan akan menggunakan lebih banyak utang. Semakin aman perusahaan dari segi pembiayaan, tambahan utang hanya meningkatkan sedikit risiko kebangkrutan.

Gambaran rata-rata profitabilitas yang diukur dengan rasio Return On Equity (ROE), rata-rata leverage yang diukur dengan rasio Debt to Equity Ratio (DER) dan rata-rata nilai perusahaan yang diukur dengan rasio Price to Book Value (PBV) pada perusahaan Sub Sektor Farmasi yang terdaftar di Bursa Efek Indonesia periode 2013-2016 penulis sajikan pada tabel 1.1 sebagai berikut:

Tabel 1.1

Gambaran Rata-rata ROE, DER dan PBV Pada Perusahaan Sub Sektor Farmasi yang Terdaftar di Bursa Efek Indonesia Periode 2013-2016

\begin{tabular}{|c|c|c|c|}
\hline Tahun & $\begin{array}{c}\text { Rata-rata } \\
\text { ROE } \\
\text { (Kali) }\end{array}$ & $\begin{array}{c}\text { Rata-rata } \\
\text { DER } \\
\text { (Kali) }\end{array}$ & $\begin{array}{c}\text { Rata-rata } \\
\text { PBV } \\
\text { (Kali) }\end{array}$ \\
\hline 2013 & 0,174 & 0,479 & 3,330 \\
\hline 2014 & 0,164 & 0,449 & 3,512 \\
\hline 2015 & 0,166 & 0,529 & 2,574 \\
\hline 2016 & 0,165 & 0,532 & 5,880 \\
\hline $\begin{array}{l}\text { Rata- } \\
\text { rata }\end{array}$ & $\mathbf{0 , 1 6 7}$ & $\mathbf{0 , 4 9 7}$ & $\mathbf{3 , 8 2 4}$ \\
\hline
\end{tabular}

Sumber: Data Diolah (www.idx.co.id)

\subsection{Rumusan Masalah}

1. Bagaimana gambaran profitabilitas, nilai perusahaan, dan leverage pada Perusahaan Sub Sektor Farmasi yang Terdaftar di Bursa Efek Indonesia.

2. Bagaimana pengaruh profitabilitas terhadap nilai perusahaan pada Perusahaan Sub Sektor Farmasi yang Terdaftar di Bursa Efek Indonesia.

3. Bagaimana kemampuan leverage dalam memoderasi hubungan profitabilitas dengan nilai perusahaan pada Perusahaan Sub
Sektor Farmasi Terdaftar di Bursa Efek Indonesia.

\subsection{Tujuan Penelitian}

1. Untuk mengetahui gambaran profitabilitas, nilai perusahaan, dan leverage pada Perusahaan Sub Sektor Farmasi yang Terdaftar di Bursa Efek Indonesia.

2. Untuk mengetahui pengaruh profitabilitas terhadap nilai perusahaan pada Perusahaan Sub Sektor Farmasi yang Terdaftar di Bursa Efek Indonesia.

3. Untuk mengetahui kemampuan leverage dalam memoderasi hubungan profitabilitas dengan nilai perusahaan pada Perusahaan Sub Sektor Farmasi Terdaftar di Bursa Efek Indonesia.

\subsection{Metode Penelitian}

Desain penelitian yang digunakan adalah Penelitian Kepustakaan (Library Reseacrh). Teknik pengumpulan data yang dilakukan menggunakan metode dokumentasi. Hasil data yang diperoleh di uji dengan uji asumsi klasik dan dianalisis secara deskriptif baik bersifat kualitatif dan kuantitatif.

\section{LANDASAN TEOR}

\subsection{Akuntansi}

Menurut Rudianto (2009:4), "akuntansi adalah sebuah sistem informasi yang menghasilkan informasi keuangan kepada pihak yang berkepentingan mengenai aktivitas ekonomi dan kondisi suatu perusahaan".

Menurut Martani, dkk (2012:136), tujuan akuntansi adalah untuk menyediakan informasi dalam bentuk laporan yang memuat posisi keuangan, hasil usaha, dan perubahan posisi keuangan lainnya secara wajar sesuai Prinsip Akuntansi Berterima Umum (PABU). Menurut Soemarso (2004:3), tujuan akuntansi adalah untuk menyajikan informasi ekonomi dari suatu kesatuan ekonomi kepada pihak-pihak yang berkepentingan.

\subsection{Analisis Laporan Keuangan}

Menurut Subramanyam dan John (2010:4), "analisis laporan keuangan (financial statement analysis) adalah aplikasi dari alat dan teknik analitis untuk laporan keuangan bertujuan umum dan data-data yang berkaitan untuk menghasilkan estimasi dan kesimpulan yang bermanfaat dalam analisis bisnis".

Menurut Subramanyam dan John (2010:2), tujuan dari analisis laporan keuangan adalah sebagai berikut :

1. Menjelaskan analisis bisnis dan hubungannya dengan analisis laporan keuangan.

2. Mengidentifikasi dan membahas berbagai jenis analisis bisnis.

3. Menguraikan komponen-komponen dalam analisis bisnis. 
4. Menjelaskan aktivitas bisnis dan hubungannya dengan laporan keuangan.

5. Menguraikan maksud masing-masing laporan keuangan dan hubungan antara laporan keuangan tersebut.

6. Mengidentifikasikan analisis atas informasi yang relevan selain laporan keuangan.

7. Menganalisis dan menginterpretasikan laporan keuangan sebagai awal analisis yang mendetail.

8. Menerapkan beberapa teknik dasar analisis laporan keuangan.

9. Menentukan dan merumuskan beberapa model penilaian fundamental.

10. Menjelaskan maksud analisis laporan keuangan dalam pasar efisien.

11. Menguraikan beberapa teori dasar investasi dan implikasinya terhadap analisis.

\subsection{Rasio Keuangan}

Menurut Jumingan (2009:242), "rasio keuangan merupakan analisis dengan jalan membandingkan satu pos dengan pos laporan keuangan lainnya baik secara individu maupun bersama-sama guna mengetahui hubungan diantara pos tertentu, baik dalam neraca maupun laporan laba rugi". Menurut Syahyunan (2015:103), "rasio keuangan merupakan analisis yang paling populer untuk mengidentifikasikan kondisi keuangan dan kinerja keuangan perusahaan".

\subsection{Profitabilitas}

Menurut Hery (2015:554), "rasio profitabilitas merupakan rasio yang digunakan untuk mengukur kemampuan perusahaan dalam menghasilkan laba dari aktivitas normal bisnisnya".

Menurut Astuti (2004:36), jenis-jenis rasio profitabilitas adalah sebagai berikut

1. Rasio Marjin atas Penjualan

Rasio ini mengukur laba per rupiah penjualan. Rumus untuk menghitung rasio ini, yaitu laba bersih dibagi dengan penjualan. Rasio ini mencerminkan kemapuan perusahaan dalam mengendalikan biaya dan pengeluaran sehubungan dengan penjualan.

2. Rasio Pengembalian atas Aktiva

Rasio ini dikenal dengan nama return on asset ratio atau ROA. Rasio ini digunakan untuk mengukur pengembalian atas total aktiva setelah bunga dan pajak. Hasil pengembalian total aktiva atau total investasi menggambarkan kinerja manajemen dalam menggunakan aktiva perusahaan untuk menghasilkan laba perusahaan.

3. Rasio Pengembalian atas Ekuitas Saham Biasa

Rasio ini menggambarkan keberhasilan atau kegagalan pihak manajemen dalam memaksimumkan tingkat hasil pengembalian investasi pemegang saham dan menekankan pada hasil pendapatan sehubungan dengan jumlah yang diinvestasikan. Rasio ini dikenal dengan return on equity atau $\mathrm{ROE}$.

\subsection{Leverage}

Menurut Sudana (2011:20), "rasio leverage merupakan rasio yang mengukur berapa besar penggunaan utang dalam pembelanjaan perusahaan".

Menurut Rudianto (2013:193), jenis rasiorasio leverage adalah sebagai berikut:

1. Debt to Equity Ratio

Rasio ini menggambarkan seberapa besar modal pemilik dapat menutupi utang-utang kepada kreditor. Semakin kecil rasio ini semakin baik. Rasio ini disebut juga rasio leverage. Untuk keamanan pihak luar rasio yang terbaik adalah jumlah modal lebih besar dari jumlah utang atau minimal sama.

\section{Debt to Total Assets Ratio}

Rasio ini merupakan perbandingan total utang jangka panjang maupun utang jangka pendek dengan total aset. Rasio ini menggambarkan kemampuan perusahaan untuk menjamin keseluruhan utang dengan aset yang dimilikinya.

3. Equity to Total Asset Ratio

Rasio ini menggambarkan hubungan antara jumlah modal terhadap total aset. Rasio ini dapat melihat seberapa jauh perusahaan dibiayai oleh modal sendiri.

\subsection{Nilai Perusahaan}

Menurut Brigham dan Joel (2010:150), "nilai perusahaan adalah sekumpulan rasio yang menghubungkan harga saham perusahaan dengan laba, arus kas, dan nilai buku per sahamnya".

Faktor-faktor yang mempengaruhi nilai perusahaan menurut Horne dan John (2012:3) antara lain:

1. Keputusan Investasi

2. Keputusan Pendanaan

3. Keputusan Manajemen Aset

\subsection{Pengaruh Profitablitas Terhadap} Nilai Perusahaan

Menurut Brigham dan Joel (2010:146), "menyatakan jika rasio likuiditas, manajemen aset, manajemen hutang, dan profitabilitas semuanya terlihat baik dan apabila kondisi ini berjalan terus menerus secara stabil maka rasio nilai pasar juga akan tinggi, harga saham juga akan meningkat".

\subsection{Hubungan Leverage dengan Nilai} Perusahaan

Menurut Sudana (2011:153), "berdasarkan signaling theory perusahaan yang mampu menghasilkan laba cenderung meningkatkan jumlah utangnya, karena tambahan pembayaran bunga akan diimbangi dengan laba sebelum pajak". Suatu perusahaan yang memprediksi labanya rendah akan cenderung 
menggunakan tingkat utang yang rendah. Semakin sukses perusahaan, kemungkinan akan menggunakan lebih banyak utang.

\section{PEMBAHASAN}

\subsection{Analisis}

\subsubsection{Analisis Deskriptif Kuantitatif}

Gambaran rata-rata Return On Equity (ROE) pada Perusahaan Sub Sektor Farmasi yang terdaftar di Bursa Efek Indonesia periode 2013-2016.

Tabel 3.1

Rata-rata ROE Pada Perusahaan Sub Sektor Farmasi yang Terdaftar di Bursa Efek Indonesia Periode 2013-2016

\begin{tabular}{|l|c|c|l|l|c|}
\hline $\begin{array}{c}\text { Kode } \\
\text { Emiten }\end{array}$ & $\begin{array}{c}\mathbf{2 0 1 3} \\
\text { (Kali) }\end{array}$ & $\begin{array}{l}\mathbf{2 0 1 4} \\
\text { (Kali) }\end{array}$ & $\begin{array}{l}\mathbf{2 0 1 5} \\
\text { (Kali) }\end{array}$ & $\begin{array}{l}\mathbf{2 0 1 6} \\
\text { (Kali) }\end{array}$ & $\begin{array}{c}\text { Rata-rata } \\
\text { Perusahaan } \\
\text { (Kali) }\end{array}$ \\
\hline DVLA & 0,138 & 0,084 & 0,111 & 0,141 & $\mathbf{0 , 1 1 8}$ \\
\hline INAF & $-\mathbf{0 , 0 9 2}$ & 0,002 & 0,011 & $-0,030$ & $-\mathbf{0 , 0 2 7}$ \\
\hline KAEF & 0,133 & 0,131 & 0,136 & 0,120 & $\mathbf{0 , 1 3 0}$ \\
\hline KLBF & 0,232 & 0,216 & 0,188 & 0,189 & $\mathbf{0 , 2 0 6}$ \\
\hline MERK & 0,343 & 0,273 & 0,301 & 0,264 & $\mathbf{0 , 2 9 5}$ \\
\hline PYFA & 0,066 & 0,027 & 0,030 & 0,049 & $\mathbf{0 , 0 4 3}$ \\
\hline SIDO & 0,155 & 0,158 & 0,168 & 0,174 & $\mathbf{0 , 1 6 4}$ \\
\hline SQBB & 0,431 & 0,447 & 0,424 & $\mathbf{0 , 4 6 6}$ & $\mathbf{0 , 4 4 2}$ \\
\hline TSPC & 0,165 & 0,142 & 0,122 & 0,118 & $\mathbf{0 , 1 3 7}$ \\
\hline $\begin{array}{l}\text { Rata- } \\
\text { rata }\end{array}$ & $\mathbf{0 , 1 7 4}$ & $\mathbf{0 , 1 6 4}$ & $\mathbf{0 , 1 6 6}$ & $\mathbf{0 , 1 6 5}$ & \\
\hline \multicolumn{7}{|c|}{ Nilai Minimum ROE } \\
\hline \multicolumn{7}{|c|}{ Rata-rata ROE Keseluruhan } & $\mathbf{0 , 1 6 7}$ \\
\hline
\end{tabular}

\section{Sumber: Data Diolah}

Berdasarkan tabel 3.1 dapat diketahui bahwa rata-rata Return On Equity (ROE) mengalami fluktuasi dan cenderung menurun. Hal ini disebabkan karena adanya penurunan laba bersih setelah pajak pada perusahaan yang terdaftar dalam Sub Sektor Farmasi seiring dengan meningkatnya total ekuitas yang di miliki perusahaan.

Gambaran rata-rata Debt to Equity Ratio (DER) Perusahaan Sub Sektor Farmasi yang Terdaftar di Bursa Efek Indonesia periode 2013-2016.

Tabel 3.2

Rata-rata DER Pada Perusahaan Sub Sektor Farmasi yang Terdaftar di Bursa Efek Indonesia Periode 2013-2016

\begin{tabular}{|c|c|c|c|c|c|}
\hline $\begin{array}{c}\text { Kode } \\
\text { Emiten }\end{array}$ & $\begin{array}{c}\mathbf{2 0 1 3} \\
\text { (Kali) }\end{array}$ & $\begin{array}{c}\mathbf{2 0 1 4} \\
\text { (Kali) }\end{array}$ & $\begin{array}{c}\mathbf{2 0 1 5} \\
\text { (Kali) }\end{array}$ & $\begin{array}{c}\mathbf{2 0 1 6} \\
\text { (Kali) }\end{array}$ & $\begin{array}{c}\text { Rata-rata } \\
\text { Perusahaan } \\
\text { (Kali) }\end{array}$ \\
\hline DVLA & 0,301 & 0,285 & 0,414 & 0,418 & $\mathbf{0 , 3 5 5}$ \\
\hline INAF & 1,191 & 1,109 & $\mathbf{1 , 5 8 8}$ & 1,400 & $\mathbf{1 , 3 2 2}$ \\
\hline KAEF & 0,522 & 0,639 & 0,738 & 1,031 & $\mathbf{0 , 7 3 3}$ \\
\hline KLBF & 0,331 & 0,266 & 0,252 & 0,222 & $\mathbf{0 , 2 6 8}$ \\
\hline MERK & 0,361 & 0,294 & 0,355 & 0,277 & $\mathbf{0 , 3 2 2}$ \\
\hline PYFA & 0,865 & 0,777 & 0,580 & 0,583 & $\mathbf{0 , 7 0 1}$ \\
\hline SIDO & 0,124 & $\mathbf{0 , 0 7 1}$ & 0,076 & 0,083 & $\mathbf{0 , 0 8 9}$ \\
\hline SQBB & 0,214 & 0,245 & 0,311 & 0,351 & $\mathbf{0 , 2 8 0}$ \\
\hline
\end{tabular}

\begin{tabular}{|r|c|c|c|c|c|}
\hline $\begin{array}{c}\text { Kode } \\
\text { Emiten }\end{array}$ & $\begin{array}{c}\mathbf{2 0 1 3} \\
\text { (Kali) }\end{array}$ & $\begin{array}{c}\mathbf{2 0 1 4} \\
\text { (Kali) }\end{array}$ & $\begin{array}{c}\mathbf{2 0 1 5} \\
\text { (Kali) }\end{array}$ & $\begin{array}{c}\mathbf{2 0 1 6} \\
\text { (Kali) }\end{array}$ & $\begin{array}{c}\text { Rata-rata } \\
\text { Perusahaan } \\
\text { (Kali) }\end{array}$ \\
\hline TSPC & 0,400 & 0,353 & 0,449 & 0,421 & $\mathbf{0 , 4 0 6}$ \\
\hline $\begin{array}{c}\text { Rata- } \\
\text { rata }\end{array}$ & $\mathbf{0 , 4 7 9}$ & $\mathbf{0 , 4 4 9}$ & $\mathbf{0 , 5 2 9}$ & $\mathbf{0 , 5 3 2}$ & \\
\hline \multicolumn{5}{|c|}{ Nilai Minimum DER } & $\mathbf{0 , 0 7 1}$ \\
\hline \multicolumn{5}{|c|}{ Nilai Maksimun DER } & $\mathbf{1 , 5 8 8}$ \\
\hline \multicolumn{3}{|c|}{ Rata-rata DER Keseluruhan } & $\mathbf{0 , 4 9 7}$ \\
\hline
\end{tabular}

\section{Sumber: Data Diolah}

Berdasarkan tabel 3.2 dapat diketahui bahwa rata-rata Debt to Equity Ratio (DER) mengalami fluktuasi dan cenderung meningkat. Hal ini disebabkan pada tahun tersebut peningkatan total utang perusahaan tidak sebanding dengan peningkatan total ekuitas tahun sebelumnya atau peningkatan total ekuitas jauh lebih tinggi dibandingkan peningkatan total utangnya.

Gambaran rata-rata Price to Book Value (PBV) pada Perusahaan Sub Sektor Farmasi yang terdaftar di Bursa Efek Indonesia periode 2013-2016 yang dapat dilihat pada tabel 3.3 sebagai berikut:

Tabel 3.3

Rata-rata PBV Pada Perusahaan Sub Sektor Farmasi yang Terdaftar di Bursa Efek Indonesia Periode 2013-2016

\begin{tabular}{|l|c|c|c|c|c|}
\hline $\begin{array}{c}\text { Kode } \\
\text { Emiten }\end{array}$ & $\begin{array}{c}\mathbf{2 0 1 3} \\
\text { (Kali) }\end{array}$ & $\begin{array}{c}\mathbf{2 0 1 4} \\
\text { (Kali) }\end{array}$ & $\begin{array}{c}\mathbf{2 0 1 5} \\
\text { (Kali) }\end{array}$ & $\begin{array}{c}\mathbf{2 0 1 6} \\
\text { (Kali) }\end{array}$ & $\begin{array}{c}\text { Rata-rata } \\
\text { Perusahaan } \\
\text { (Kali) }\end{array}$ \\
\hline DVLA & 2,694 & 1,949 & 1,455 & 1,765 & $\mathbf{1 , 9 6 6}$ \\
\hline INAF & 0,803 & 1,859 & 0,878 & $\mathbf{2 5 , 1 9 2}$ & $\mathbf{7 , 1 8 3}$ \\
\hline KAEF & 2,038 & 4,548 & 2,632 & 6,877 & $\mathbf{4 , 0 2 3}$ \\
\hline KLBF & 7,226 & 9,143 & 5,913 & 5,963 & $\mathbf{7 , 0 6 1}$ \\
\hline MERK & 6,074 & 6,473 & 6,410 & 7,074 & $\mathbf{6 , 5 0 8}$ \\
\hline PYFA & 0,838 & 0,744 & 0,592 & 1,014 & $\mathbf{0 , 7 9 7}$ \\
\hline SIDO & 3,999 & 3,473 & 3,175 & 2,828 & $\mathbf{3 , 3 6 9}$ \\
\hline SQBB & 0,280 & $\mathbf{0 , 2 6 4}$ & 0,275 & 0,274 & $\mathbf{0 , 2 7 3}$ \\
\hline TSPC & 3,826 & 3,155 & 1,836 & 1,935 & $\mathbf{2 , 6 8 8}$ \\
\hline $\begin{array}{c}\text { Rata- } \\
\text { rata }\end{array}$ & $\mathbf{3 , 0 8 7}$ & $\mathbf{3 , 5 1 2}$ & $\mathbf{2 , 5 7 4}$ & $\mathbf{5 , 8 8 0}$ & \\
\hline \multicolumn{5}{|c|}{ Nilai Minimum PBV } \\
\hline \multicolumn{5}{|c|}{ Maksimun PBV } & $\mathbf{0 , 2 6 4}$ \\
\hline
\end{tabular}

\section{Sumber: Data Diolah}

Berdasarkan tabel 3.3 di atas, diketahui bahwa rata-rata Price to Book Value (PBV) mengalami fluktuasi dan cenderung meningkat. Hal ini disebabkan terjadinya peningkatan harga saham dan peningkatan nilai buku per saham, tetapi kenaikan harga saham lebih tinggi dari kenaikan nilai buku per saham.

\subsubsection{Analisis Deskriptif Kuantitatif}

1. Analisis Regresi

1) Analisis Regresi Linier Sederhana

Hasil pengujian dengan menggunakan analisis regresi linier sederhana dapat dilihat pada tabel 3.4 sebagai berikut: 
Tabel 3.4

Hasil Analisis Regresi Linear Sederhana Coefficients $^{a}$

\begin{tabular}{|cc|c|c|c|}
\hline \multirow{2}{*}{ Model } & \multicolumn{2}{|c|}{$\begin{array}{c}\text { Unstandardized } \\
\text { Coefficients }\end{array}$} & $\begin{array}{c}\text { Standardized } \\
\text { Coefficients }\end{array}$ \\
\cline { 2 - 5 } & B & $\begin{array}{c}\text { Std. } \\
\text { Error }\end{array}$ & Beta \\
\hline \multirow{2}{*}{1} & $\begin{array}{c}\text { (Constant) } \\
\text { ROE }\end{array}$ & $\mathbf{4 , 4 3 0}$ & 1,215 & \\
$\mathbf{2}$ & $-\mathbf{3 , 6 1 6}$ & 5,702 &,- 108 \\
\hline \multicolumn{2}{|c|}{ a. Dependent Variable: PBV }
\end{tabular}

Sumber: Hasil Pengolahan Data (SPSS 20), 2018

Berdasarkan tabel 3.4 di atas, model persamaan regresi linear sederhana yang diperoleh adalah:

$$
\hat{\mathbf{Y}}=4,430-3,616 \mathrm{X}
$$

Artinya profitabilitas berpengaruh negatif terhadap nilai perusahaan Pada Perusahaan Sub Sektor Farmasi yang terdaftar di Bursa Efek Indonesia periode 2013-2016.

\section{2) Analisis Regresi Moderasi/Moderated}

Regression Analysis

Tabel 3.5

Hasil Moderated Regression Analysis Coefficients $^{\mathrm{a}}$

\begin{tabular}{|l|c|c|c|}
\hline Model & \multicolumn{2}{|c|}{$\begin{array}{c}\text { Unstandardized } \\
\text { Coefficients }\end{array}$} & $\begin{array}{c}\text { Standardized } \\
\text { Coefficients }\end{array}$ \\
\cline { 2 - 4 } & $\mathrm{B}$ & $\begin{array}{c}\text { Std. } \\
\text { Error }\end{array}$ & Beta \\
\hline (Constant) & $\mathbf{1 , 8 8 4}$ & 2,462 & \\
ROE & $\mathbf{8 , 6 0 7}$ & 11,685 &, 257 \\
DER & $\mathbf{3 , 3 0 6}$ & 2,741 &, 274 \\
INTERAKSI & $\mathbf{- 2 1 , 4 5 4}$ & 25,704 &,- 245 \\
\hline
\end{tabular}

a. Dependent Variable: PBV

Sumber: Hasil Pengolahan Data (SPSS 20), 2018

Berdasarkan tabel 3.5 di atas, model persamaan Moderated Regression Analysis (MRA) yang diperoleh adalah:

$\hat{Y}=1,884+8,607 X_{1}+3,306 X_{2}-21,454 X_{1} \cdot X_{2}+e$

Artinya leverage memperlemah hubungan profitabilitas dengan nilai perusahaan Pada Perusahaan Sub Sektor Farmasi yang terdaftar di Bursa Efek Indonesia periode 2013-2016.

2. Koefisien Korelasi (r) dan Koefisien Determinasi (R)

1) Profitabilitas Terhadap Nilai Perusahaan Tabel 3.6

Hasil Koefisien Korelasi dan Koefisien Determinasi Model Summary

\begin{tabular}{|c|c|c|c|c|}
\hline Model & $R$ & $R$ Square & $\begin{array}{c}\text { Adjusted R } \\
\text { Square }\end{array}$ & $\begin{array}{c}\text { Std. Error of the } \\
\text { Estimate }\end{array}$ \\
\hline 1 & $\mathbf{1 0 8}^{\mathrm{a}}$ & $\mathbf{, 0 1 2}$ &,- 017 & 4,500718 \\
\hline
\end{tabular}

(Constant), ROE

Sumber: Hasil Pengolahan Data (SPSS 20), 2018

Berdasarkan tabel 3.6 di atas, terlihat bahwa nilai $r$ adalah 0,108 yang berarti terdapat korelasi atau hubungan yang sangat rendah antara variabel nilai perusahaan dengan variabel independennya yaitu profitabilitas. Sementara koefisien determinasi
(R) adalah 0,12 , hal ini berarti $1,2 \%$ variasi dari nilai perusahaan dijelaskan oleh variabel profitabilitas sedangkan sisanya $98,8 \%$ dijelaskan oleh faktor lain yang tidak dimasukkan dalam model regresi.

2) Hubungan Leverage Sebagai Variabel

Moderating Dengan Nilai Perusahaan Tabel 3.7

Hasil Koefisien Korelasi dan Koefisien Determinasi MRA Model Summary

\begin{tabular}{|l|c|c|c|c|}
\hline Model & $R$ & $R$ Square & $\begin{array}{c}\text { Adjusted R } \\
\text { Square }\end{array}$ & $\begin{array}{c}\text { Std. Error of the } \\
\text { Estimate }\end{array}$ \\
\hline $\mathbf{1}$ & $\mathbf{2 5 0 ^ { \mathbf { a } }}$ & $\mathbf{, 0 6 2}$ & $-0,026$ & 4,518968 \\
\hline
\end{tabular}

a. Predictors: (Constant), INTERAKSI, DER, ROE

b. Dependent Variable: PBV

Sumber: Hasil Pengolahan Data (SPSS 20), 2018

Berdasarkan tabel diatas dapat dilihat bahwa nilai $r$ sebesar 0,250 yang berarti bahwa terdapat korelasi atau hubungan yang rendah antara variabel dependen atau nilai perusahaan dengan variabel moderating yaitu leverage. Sementara koefisien determinasi $(R)$ adalah 0,062 , artinya $6,2 \%$ variasi dari nilai perusahaan dijelaskan oleh variabel moderating leverage sedangkan sisanya 93,8\% dijelaskan oleh faktor lainnya yang tidak dimasukkan dalam model regresi. Dengan demikian leverage sebagai variabel moderating terbukti memiliki hubungan yang rendah untuk memperkuat hubungan profitabilitas dengan nilai perusahaan.

\section{Uji Hipotesis}

1) Uji Hipotesis Pertama

Untuk uji t hasil pengolahan data pada penelitian ini disajikan pada tabel sebagai berikut:

Tabel 3.8

Hasil Uji t

Coefficients $^{\mathrm{a}}$

\begin{tabular}{|c|c|c|}
\hline Model & $\mathrm{T}$ & Sig. \\
\hline (Constant) & 3,647 &, 001 \\
ROE & $-\mathbf{6 3 4}$ &, 530 \\
\hline
\end{tabular}

a. Dependent Variable: PBV

Sumber: Hasil Pengolahan Data (SPSS 20), 2018

Berdasarkan hasil uji t pada tabel $3.8 \mathrm{di}$ atas, nilai thitung pada variabel $X$ (Profitabilitas) sebesar $-0,634$ lebih kecil dari tabel sebesar 2,03452 atau dapat dikatakan -0,634 < 2,03452 dengan taraf signifikan 0,530 lebih besar dari nilai $\alpha=0,05$, maka $\mathrm{H}_{0}$ diterima yang artinya profitabilitas berpengaruh negatif tidak signifikan terhadap nilai perusahaan pada Perusahaan Sub Sektor Farmasi yang terdaftar di Bursa Efek Indonesia periode 2013-2016. 


\section{2) Uji Hipotesis Kedua}

Untuk uji regresi moderasi hasil pengolahan data pada penelitian ini disajikan pada tabel 3.9 sebagai berikut:

Tabel 3.9

Hasil Uji Moderated Regression Analysis (MRA)

Coefficients $^{\mathrm{a}}$

\begin{tabular}{|c|c|c|c|}
\hline \multicolumn{3}{|c|}{ Coefficients $^{\mathrm{a}}$} \\
\multicolumn{2}{|c|}{ Model } & $\mathrm{T}$ & Sig. \\
\hline \multirow{4}{*}{1} & (Constant) &, 765 &, 450 \\
& ROE &, 737 &, 467 \\
& DER & 1,206 &, 237 \\
& INTERAKSI &,- 835 & $\mathbf{4 1 0}$ \\
\hline
\end{tabular}

a. Dependent Variable: PBV

Sumber: Hasil Pengolahan Data (SPSS 20), 2018

Berdasarkan hasil uji moderated regression analysis (MRA) dapat diketahui bahwa nilai signifikan sebesar 0,410 lebih besar dari $\alpha=$ 0,05 atau $0,410>0,05$, maka $\mathrm{H}_{0}$ diterima artinya leverage mampu memoderasi namun tidak signifikan hubungan antara profitabilitas dengan nilai perusahaan pada Perusahaan Sub Sektor Farmasi yang terdaftar di Bursa Efek Indonesia Periode 2013-2016

\subsection{Evaluasi}

1. Evaluasi Profitabilitas Pada Perusahaan

Sub Sektor Farmasi yang Terdaftar di

Bursa Efek Indonesia Periode 2013-2016

Berdasarkan hasil penelitian, diketahui bahwa rasio ROE pada Perusahaan Sub Sektor Farmasi yang terdaftar di Bursa Efek Indonesia periode 2013-2016 mengalami fluktuasi dan cenderung menurun. Kecenderungan menurun. Hal ini disebabkan oleh peningkatan laba bersih setelah pajak pada Perusahaan Sub Sektor Farmasi yang terdaftar di Bursa Efek Indonesia periode 2013-2016. Nilai rata-rata minimum rasio ROE per tahun pada Perusahaan Sub Sektor Farmasi yang terdaftar di Bursa Efek Indonesia periode 2013-2016 berada pada tahun 2014 yaitu sebesar 0,164, artinya untuk setiap Rp 1 ekuitas yang digunakan perusahaan untuk mendanai aktivitas operasionalnya menghasilkan laba bersih setelah pajak sebesar Rp 0,164 untuk tahun tersebut.

Hal yang menjadi penyebab rasio ROE mencapai tingkat minimum adalah total laba bersih setelah pajak lebih kecil dibandingkan total ekuitasnya. Untuk meningkatkan rasio ROE, perusahaan sebaiknya meningkatkan penjualan dan efisiensi perusahaan dalam mengelola aset, liabilitas dan ekuitas yang dimiliki perusahaan agar dapat memaksimalkan laba yang hendak dicapai perusahaan. Pemaksimalan laba perusahaan akan berpengaruh terhadap peningkatan nilai perusahaan sehingga para investor tertarik untuk berinvestasi pada perusahaan yang bersangkutan.

2. Evaluasi Leverage Pada Perusahaan Sub Sektor Farmasi yang Terdaftar di Bursa Efek Indonesia Periode 2013-2016

Hasil penelitian menunjukkan bahwa DER pada Perusahaan Sub Sektor Farmasi yang terdaftar di Bursa Efek indonesia periode 20132016 mengalami fluktuasi dan cenderung meningkat. Nilai rata-rata maksimum DER per tahun pada Perusahaan Sub Sektor Farmasi yang terdaftar di Bursa Efek Indonesia periode 2013-2016 berada pada tahun 2016 yaitu sebesar 0,532 yang artinya setiap Rp 1 ekuitas digunakan untuk menjamin utang sebesar $\mathrm{Rp}$ 0,532 pada tahun tersebut. Pada saat DER perusahaan berada pada tingkat maksimum, hal ini disebabkan oleh mayoritas perusahaan Sub Sektor farmasi yang terdaftar di Bursa Efek Indonesia pada tahun tersebut menggunakan lebih banyak hutang untuk mendanai aktivitas operasi perusahaannya. Sebaiknya mengendalikan hutang dengan cara menggunakan hutang untuk meningkatkan produktivitas perusahaan, produktivitas meningkat maka pendapatan meningkat ketika pendapatan meningkat maka laba perusahaan akan meningkat ketika laba perusahaan meningkat maka nilai perusahaan juga akan meningkat.

3. Evaluasi Nilai Perusahaan Pada Perusahaan Sub Sektor Farmasi yang Terdaftar di Bursa Efek Indonesia Periode 2013-2016

Hasil penelitian ini menunjukkan bahwa nilai PBV pada Perusahaan Sub Sektor Farmasi periode 2013-2016 berfluktuasi dan cenderung meningkat. Fluktuasi nilai perusahaan tersebut terjadi karena peningkatan harga saham dan peningkatan nilai buku, tetapi kenaikan harga saham lebih tinggi dari kenaikan nilai buku per sahamnya. Nilai rata-rata minimum PBV per tahun Perusahaan Sub Sektor Farmasi yang terdaftar di Bursa Efek Indonesia periode 2013-2016 berada pada tahun 2015 yaitu sebesar 2,512 yang artinya meskipun termasuk ke dalam klasifikasi nilai rata-rata minimum akan tetapi harga saham tidak termasuk dalam kategori undervalued. Untuk mempertahankanya tingkat PBV tersebut, sebaiknya perusahaan tetap melakukan pengkajian ulang atas penggunaan aset, utang, dan ekuitas yang bertujuan untuk menjaga dan meningkatkan profitabilitas perusahaan yang akan memberikan dampak positif terhadap nilai perusahaan. 
4. Evaluasi Pengaruh Profitabilitas Terhadap Nilai Perusahaan Pada Perusahaan Sub Sektor Farmasi yang Terdaftar di Bursa Efek Indonesia Periode 2013-2016

Berdasarkan hasil pengujian analisis regresi linear sederhana yang telah dilakukan, dapat diketahui bahwa profitabilitas berpengaruh negatif terhadap nilai perusahaan. Hal ini dapat dilihat dari persamaan regresi yaitu: $\hat{\mathbf{Y}}=\mathbf{4 , 4 3 0}$ - 3,616X. Nilai konstanta sebesar 4,430 artinya ketika profitabilitas sama dengan nol maka nilai perusahaan adalah sebesar 4,430. Koefisien regresi profitabilitas sebesar $-3,616$ menunjukkan bahwa profitabilitas memiliki pengaruh negatif terhadap nilai perusahaan yang artinya untuk setiap kenaikan profitabilitas sebesar 1 satuan maka akan menyebabkan penurunan nilai perusahaan sebesar 3,616 satuan. Kondisi ini tidak sejalan dengan pendapat Brigham dan Joel (2010:146), "menyatakan jika rasio likuiditas, manajemen aset, manajemen hutang, dan profitabilitas semuanya terlihat baik dan apabila kondisi ini berjalan terus menerus secara stabil maka rasio nilai pasar juga akan tinggi, harga saham juga akan meningkat".

5. Evaluasi Hubungan Leverage Sebagai Variabel Moderating Dengan Nilai Perusahaan Pada Perusahaan Sub Sektor Farmasi yang Terdaftar di Bursa Efek Indonesia Periode 2013-2016

Berdasarkan hasil uji regresi moderasi menggunakan uji interaksi Moderated Regression Analysis (MRA) menunjukkan bahwa Leverage yang diproksikan dengan Debt to Equity Ratio (DER) mampu memoderasi namun tidak signifikan hubungan antara profitabilitas dengan nilai perusahaan. Hal tersebut dibuktikan dari hasil regresi moderasi yang dilakukan yaitu hasil interaksi antara ROE dan DER menghasilkan signifikan sebesar 0,410 lebih besar dari $\alpha=0,05$ atau $0,410>0,05$. Maka dapat disimpulkan bahwa leverage mampu memoderasi namun tidak signifikan hubungan antara profitabilitas dengan nilai perusahaan pada Perusahaan Sub Sektor Farmasi yang terdaftar di Bursa Efek Indonesia periode 2013-2016. Kondisi ini tidak sejalan dengan pendapat Menurut Sudana (2011:153), "berdasarkan signaling theory perusahaan yang mampu menghasilkan laba cenderung meningkatkan jumlah utangnya, karena tambahan pembayaran bunga akan diimbangi dengan laba sebelum pajak".

\section{KESIMPULAN DAN SARAN}

\subsection{Kesimpulan}

1. Berdasarkan hasil penelitian secara keseluruhan nilai rata-rata ROE mengalami fluktuasi dan cenderung menurun pada
Perusahaan Sub Sektor Farmasi yang terdaftar di Bursa Efek Indonesia periode 2013-2016.

2. Berdasarkan hasil penelitian secara keseluruhan nilai rata-rata DER mengalami fluktuasi dan cenderung meningkat pada Perusahaan Sub Sektor Farmasi yang terdaftar di Bursa Efek Indonesia periode 2013-2016.

3. Berdasarkan hasil penelitian secara keseluruhan nilai rata-rata PBV mengalami fluktuasi dan cenderung meningkat pada Perusahaan Sub Sektor Farmasi yang terdaftar di Bursa Efek Indonesia periode 2013-2016.

4. Dari hasil pengujian regresi linear sederhana diketahui bahwa profitabilitas berpengaruh negatif terhadap nilai perusahaan Pada Perusahaan Sub Sektor Farmasi yang terdaftar di Bursa Efek Indonesia periode 2013-2016.

5. Dari hasil pengujian regresi moderasi diketahui bahwa leverage memperlemah hubungan profitabilitas dengan nilai perusahaan Pada Perusahaan Sub Sektor Farmasi yang terdaftar di Bursa Efek Indonesia periode 2013-2016.

6. Dari hasil uji koefisien korelasi dan determinasi profitabilitas terhadap nilai perusahaan diketahui bahwa terdapat korelasi atau hubungan yang sangat rendah antara nilai perusahaan dengan profitabilitas dan nilai perusahaan lebih banyak dipengaruhi oleh faktor lain yang tidak diteliti dalam penelitian.

7. Dari hasil uji koefisien korelasi dan determinasi hubungan leverage sebagai variabel moderating dengan nilai perusahaan diketahui bahwa terdapat korelasi atau hubungan yang rendah antara variabel dependen atau nilai perusahaan dengan variabel moderating yaitu leverage dan nilai perusahaan lebih banyak dipengaruhi oleh faktor lain diluar penelitian

8. Dari hasil uji hipotesis pertama dapat disimpulkan bahwa profitabilitas berpengaruh tidak signifikan terhadap nilai perusahaan pada Perusahaan Sub Sektor Farmasi yang terdaftar di Bursa Efek Indonesia periode 2013-2016.

9. Dari hasil uji hipotesis kedua dapat disimpulkan bahwa leverage mampu memoderasi namun tidak signifikan hubungan antara profitabilitas dengan nilai perusahaan pada Perusahaan Sub Sektor Farmasi yang terdaftar di Bursa Efek Indonesia periode 2013-2016.

4.2. Saran

1. Untuk meningkatkan profitabilitas pada perusahaan sebaiknya perusahaan lebih meningkatkan penjualan yang diikuti dengan perbaikan pada kebijakan untuk 
mengoptimalkan laba yang baik, sehingga ketika laba perusahaan meningkat maka harga saham juga meningkat dan berdampak pada nilai perusahaan dan hal ini akan menjadi daya tarik bagi investor untuk berinvestasi.

2. Untuk perusahaan yang menggunakan leverage yang tinggi dalam membiayai aktivitas operasional perusahaan sebaiknya mengendalikan hutang dengan cara menggunakan hutang untuk meningkatkan produktivitas perusahaan, produktivitas meningkat maka pendapatan meningkat ketika pendapatan meningkat maka laba perusahaan akan meningkat ketika laba perusahaan meningkat maka nilai perusahaan juga akan meningkat dan hal ini akan menjadi daya tarik investor untuk berinvestasi.

3. Untuk meningkatkan nilai perusahaan sebaiknya perusahaan melakukan pengendalian yang baik terhadap manajemen aset, manajemen utang, dan ekuitas yang dimiliki perusahaan dengan tujuan untuk meningkatkan profitabilitas perusahaan yang akan berpengaruh terhadap nilai perusahaan.

4. Agar peningkatan profitabilitas tidak menurunkan nilai perusahaan sebaiknya perusahaan membagikan dividen kepada pemegang saham sehingga pemegang saham merasa nyaman dan tertarik untuk menanamkan sahamnya pada Perusahaan Sub Sektor Farmasi yang terdaftar di Bursa Efek Indonesia.

\section{E. DAFTAR PUSTAKA}

Astuti, Dewi. 2004. Manajemen Keuangan Perusahaan. Cetakan pertama, Jakarta : Ghalia Indonesia.

Brigham, Eugene F. dan Joel F. Houston. 2010. Dasar-dasar Manajemen Keuangan. Buku 1. Edisi 11. Jakarta : Salemba Empat.

Bursa Efek Indonesia, http://www.idx.co.id/. Tahun akses 2018.

Hery. 2015. Pengantar Akuntansi. Jakarta : PT Grasindo.

Horne, James C.Van dan John M. Wachowicz. 2012. Prinsip-prinsip Manajemen Keuangan. Edisi 13, Jilid I. Jakarta : Salemba Empat.

Jumingan.2009. Analisis Laporan Keuangan. Cetakan 3. Jakarta : PT Bumi Aksara.

Martani, Dwi, dkk.2012. Akuntansi Keuangan Menengah Berbasis PSAK. Jakarta : Salemba Empat.

Rudianto. 2009. Pengantar Akuntansi. Jakarta : Erlangga

2013. Akuntansi Manjemen. Jakarta : Erlangga.

Soemarso. 2004. Akuntansi Suatu Pengantar. Jakarta : Salemba Empat.
Subramanyam, K.R, dan John J. Wild. 2010. Analisis Laporan Keuangan. Edisi 10. Jakarta : Salemba Empat.

Sudana, I Made. 2011. Manajemen Keuangan Perusahaan : Teori dan Praktik. Jakarta : Erlangga.

Syahyunan. 2015. Manajemen Keuangan : Perencanaan, Analisis dan Pengendalian Keuangan. Edisi 2. Medan : USU Press. 